\title{
Tourism-induced emission in Sub-Saharan Africa: A Panel Study for Oil-Producing and Non-oil-Producing countries
}

\author{
Festus Victor Bekun ${ }^{1,2}\left(\mathbb{D} \cdot\right.$ Bright Akwasi Gyamfi ${ }^{3} \cdot$ Ruth Oluyemi Bamidele $^{4} \cdot$ Edmund Ntom Udemba $^{5}$
}

Received: 3 August 2021 / Accepted: 17 December 2021 / Published online: 31 January 2022

(c) The Author(s), under exclusive licence to Springer-Verlag GmbH Germany, part of Springer Nature 2021

\begin{abstract}
The tourism industry is undoubtedly among the largest contributors to economic growth and employment generation in most economies of the world, and Africa is not an exception as outlined by World Tourism Organization (UNWTO). Thus, many countries in sub-Saharan Africa (SSA) are paying more attention to tourism development as alternative growth path to boost their economies. However, the tourism-induced growth is not void of its environmental issues. To this end, this study using recent econometrics analysis explored the nexus between tourism arrival GDP growth, urbanization, carbon dioxide emission, and foreign direct investment for oil and non-oil sub-Saharan Africa (SSA) countries, that is, to ascertain the real impacts of tourism and FDI on the environmental performance of the regions. Empirical results show that tourism, GDP growth, and FDI dampen the quality of the environment. For instance, a $1 \%$ increase in tourism activities worsens the quality of the environment by $1.09 \%$. Interestingly, renewable energy shows statistical strength to improve environmental quality. The causality analysis resonates with the outcomes of the regression by giving credence to one-way causality between tourism and carbon dioxide emission. A similar trend of causality is seen between FDI and carbon dioxide emission and urbanization and carbon dioxide emission. Thus, as a policy prescription, strict environmental guidelines and regulations are necessary for controlling the unhealthy and undue economic activities that are suspected to impact environment negatively.
\end{abstract}

Keywords Green Tourism · Sustainable development · Carbon reduction · Panel econometrics · Sub-Saharan Africa

Responsible editor: Ilhan Ozturk

Festus Victor Bekun

fbekun@gelisim.edu.tr

Bright Akwasi Gyamfi

brightgyamfi1987@gmail.com

Ruth Oluyemi Bamidele

rumikdanem@gmail.com

Edmund Ntom Udemba

eudemba@gelisim.edu.tr

1 Faculty of Economics Administrative and Social Sciences, Istanbul Gelisim University, Istanbul, Turkey

2 Department of Economic Security, South Ural State University, 76, Lenin Aven, Chelyabinsk, Russia 454080

3 Faculty of Economics and Administrative Sciences, Cyprus International University, Via Mersin 10, Nicosia, North Cyprus, Turkey

4 Faculty of Tourism, Eastern Mediterranean University, Via Mersin 10, Famagusta, Northern Cyprus, Turkey

5 Faculty of Economics Administrative and Social Science, Istanbul Gelisim University, Istanbul, Turkey

\section{Introduction}

Africa is one of the regions of the world with a steady and fastest tourism growth before the COVID-19 pandemic outbreak. According to World Trade and Tourism Organization (WTTO, 2019) and the United Nations World Tourism Organization (UNWTO, 2020), the continent actually recorded a growth of 4\% in 2019 the same as Europe, but even ahead of the USA that recorded just $2 \%$ growth in the same period. Moreover, the sector also generated 1 out of every 10 jobs created in the same year across the globe including 19.5milion jobs in sub-Saharan Africa in the same year 2013. Tourism growth also added US\$170.7billion to the GDP of the continent in the same year (UNWTO, 2020; Yusuf, 2016). This is also alluded to in the context of the EU by Adedoyin et al. (2021a, 2021b, 2021c) in their investigation of the linkages between economic complexities, a thriving and competitive tourism industry and environmental consequences within the EU. The authors stressed the huge economic benefits of tourism industry to the EU economic growth and development, which includes job 
creation, increased foreign exchange earnings, and GDP growth among others.

However, the tourism industry had been repeatedly identified as one of the major contributors of between 5 and $8 \%$ to the global carbon emission and by implications to global warming, especially since the tourism industry is known to be highly energy dependent across its value chain and sectors, such as the hotel and accommodation, aviation and airline, food and beverages, and tourism attractions (Adedoyin et al. 2021a, 2021b, 2021c; UNWTO, 2020; WTTC, 2019; Alola \& Alola, 2018). Adedoyin et al. (2021a, 2021b, 2021c) argued that many tourist destinations are now known to be highly susceptible to different effects of climate change as a result of tourism activities Hence, the contribution of tourism to economic growth as well as the negative effect on the environment in many countries across the globe is well documented in the literature and has generated the concept of tourist carbon footprint (TCF) due to the escalation in energy consumption with environmental degradation as one negative consequences increase in tourism and tourist activities (Adedoyin et al. (2021a, 2021b, 2021c; Adedoyin, \& Bekun, 2020; Adedoyin et al. 2021a, 2021b, 2021c; Gao, \& Zhang, 2019; Qureshi et al., 2019; Lasisi et al., 2020; Gyamfi et al., 2021a; Sharif et al., 2020; Baloch et al., 2021). Yet, Adedoyin et al. 2021a, 2021b, 2021c argued that the level of economic complexities vis-à-vis knowledge, skill, and sophistication in methods of production and delivery of goods and services helps in reducing the negative impact on the environment.

Findings, however, reveal that most investigations relating to this study focused mainly on developed economies in Europe, America, and some Asian countries (Adedoyin et al. 2021a, 2021b, 2021c; Adedoyin, \& Zakari, 2020; Balsalobre-Lorente, \& Leitão, 2020; Ozpolat et al., 2021; Shaheen et al., 2019) with little searchlight on sub-Saharan Africa.

Meanwhile, a number of studies indicated that the general increase in energy consumption and improvement in economic growth on the continent of Africa are often with some levels of environmental consequences (Ssali et al., 2019; Hanif, 2018; Zaidi, \& Saidi, 2018). That notwithstanding, the actual connection and implication between tourism-led growth, energy consumption (renewable and nonrenewable), and environmental pollution such as carbon emission are not receiving enough attention in the extant literature. The few pieces of available evidence of such studies are often on the Southern African subregion (Sarpong et al., 2020, and Lee \& Brahmasrene, 2016), or on other variables on sub-Saharan Africa in general, while some particularly focus attention on oil-producing countries on the continent and comparison between the oil-based emission and tourism-linked $\mathrm{CO}_{2}$ emission.

Therefore, this study intends to fill this existing void particularly on the relationship between tourism-led growth, energy consumption in terms of renewable sources on the one hand, and fossil fuel-based energy usage on the other, and the effect on the environment in a panel of sub-Saharan African context. The focus is on a panel of some identified major tourism destinations in sub-Saharan Africa from 2008 to 2018, with evidence of increased international tourist's arrival in recent decades, increased GDP, as well as a reasonable level of energy mix and consumption in order to probe cointegration among the stated variables and environmental pollution caused particularly by greenhouse gas (GHG) emission. Similar investigations had been carried out on other countries and regions such as the UK, EU, and Asia and from the perspective of the role of research and development in environmental sustainability (Adedoyin et al., 2021; Adedoyin and Bekun, 2020; Adedoyin, \& Zakari, 2020; Shittu et al., 2021).

The contribution of this study includes the fact that it further expands our understanding of the actual causality between tourism and energy consumption pattern (renewable and non-renewable energy consumption), and $\mathrm{CO}_{2}$ emission and global warming as it relates to the continent of Africa. In other words, the novelty of this current study is that it raises and highlights the argument that the type of energy being consumed either fossil fuel or green or renewable energy sources matters in terms of the causality between energy consumption and carbon emission and tourism activities. Empirical findings according to Adedoyin \& Zakari (2020) revealed that most investigations on this topic in relation to Africa majorly focus on total energy consumption with positive impact on economic growth in most cases, without accounting for any differences that might occur in $\mathrm{CO}_{2}$ emission levels where renewable energy consumption is significant in the totality of energy consumed. Most economies across the globe are on a perpetual route for alternative growth path. Among the prominent growth path are Solow growth model which considered capital and labor as key growth determinants. More recently, the tourism-led growth hypothesis (TLGH) emerged in the extant literature which outlined the pivotal role of tourism arrival to economic growth. The current study is built on the intuition that increase or high influx of tourism activities, especially for SSA, is on the high. To this end, we make the assertion that international tourism arrival will induce an increase in energy demand for tourism activities and by extension induce environmental degradation, especially consumption of energy from fossil fuel base. This twin growth catalyst of tourism and energy consumption has its environmental consequences (Ozcan et al., 2021; Katircioglu, 2014). Further backing for the current study stems from the tourisminduced environmental degradation hypothesis which is based on the trade-off between economic growth and tourism on environmental quality. Our study is distinct by the consideration of both non-oil- and oil-dependent countries 
of SSA countries for the first time in the extant literature by addition of control variables such as FDI and urbanization to explore theme. Thus, our current study augments the EKC framework with tourism and additional macroeconomic variables for more robust inferences for the study area in a linear fashion without consideration for quadratic form. The implication of this is that it will inform policy-makers in both the tourism sector and those in charge of the general economy in various countries in the region to identify the areas they need to focus their policy direction on sustainability, economy, and tourism. This is also germane and contributes to the ongoing debate on combating climate change and global warming using increased renewable energy consumption as against fossil fuel sources across the globe as corroborated to by Adedoyin et al. (2020a). Furthermore, scholars can use the findings from this study to further substantiate appropriately and generalize the impact of tourism-led growth hypothesis and the nexus between it and carbon pollution in the African context.

The remaining segments of this study are organized as follows: The next section is dedicated to the review of existing and relevant literature on the subject matter; section three is on methodology, followed by section four that presents the findings and discussion, while section five is on conclusion, implications, limitations, and suggestions for further studies.

\section{Review of Existing literature}

Unarguably, empirical evidence suggests that energy consumption rate is analogous to the rate of economic development in any country from the global North to the global South. Hence, the higher the energy poverty and lower energy consumption rate a country is, the higher the poverty rate and poor economic growth and development in such countries and vis-à-vis. Yet, regulatory environment and economic policy uncertainty are also found to either mitigate or complicate the situation (Adedoyin et al., 2020a; Adedoyin et al. 2021a, 2021b, 2021c; Adedoyin, \& Zakari, 2020; Aslan et al., 2021; El Menyari, 2021). In a study involving global top ten tourism destinations, Adedoyin et al. (2021a, 2021b, 2021c) opined that effective implementation of environmental and renewable energy policies plays a huge role in taming the negative impact of energy consumption on environment. While alluding to this narrative, Adedoyin et al. (2021a, 2021b, 2021c) suggested that Japan is capable of achieving her target of cleaner environment and an increase in greener energy consumption in the complex economy if attention is given to policies that dissuade fossil fuel energy consumption while promoting cleaner energy, and economic growth and complexities. This also aligns with findings by Adedoyin et al. (2020a, 2020b) on the BRICS countries where stringent energy and environmental regulatory framework curb environmental degradation as they opened up for economic growth and development was recommended by the authors.

Similarly, and as earlier noted, the tourism industry is no doubt one of the largest energy-consuming industries and also a huge contributor to national GDP and employment generation in most countries of the world, and Africa is not an exception. Thus, many developing countries including those in sub-Saharan Africa (SSA) are also paying more attention to tourism development to boost their economies. The extant literature substantiates this claim, and especially on the connection between tourism-led economic growth, and other variables including energy consumption, energy mix, foreign direct investment, and environmental pollution and degradation (El Menyari, 2021; Ssali et al., 2019; Alola \& Alola, 2019 Hanif, 2018; Zaidi, \& Saidi, 2018; Adedoyin, \& Bekun, 2020, Gao, \& Zhang, 2019; Qureshi et al., 2019; Sarpong et al., 2020; Lee, \& Brahmasrene, 2016; Mensah et al., 2019), although a plethora of studies focused mainly on advanced and industrialized economies such as the UK and EU (Adedoyin et al. 2021a, 2021b, 2021c; Lasisi et al 2021; De Vita et al. 2015; Iwata and Okada, 2013; Katircioglu et al., 2014; Nissan et al., 2011).

Unfortunately, there was a dramatic and almost spontaneous downward trend in the growth from Q1, 2020, after the confirmation of the deadly corona virus in many countries of the world, and the non-medical containment measures (border closure, lockdown, shutdowns, flights restrictions, etc.) by March 2020 in many countries, which marked the beginning of a new era not only in tourism, but also in world history, also known as the 'new normal' (BBC News, 2020; UNWTO, 2020; IMF/WEO, 2020; Ozili and Arun, 2020). Nonetheless, despite the above glooming picture of tourism in the year 2020, the projection is that by the middle of 2021, tourism will bounce back, though with the caution that it might take up to $2 \frac{1}{2}$ to 4 years before we can see tourism returning to the 2019 level (UNWTO, 2020). Conversely, the inadvertent drastic reduction in energy consumption and emission due to lockdowns, restriction of vehicular and human movement, etc., lead to emergence of clearer skylines, cleaner air and environment in many global cities including the hitherto reputed most polluted cities in the world such as Delhi, Beijing, Tokyo, and many European and American cities. Apparently, this signals a positive and new hope for what is possible if the global business community is willing and intentional to tackle environmental pollution, reduce emission, and mitigate climate change by replacing energy consumption from fossil fuel sources and other sustainable practices in the tourism value chain and other energy-intensive industries across the globe.

Thus, with or without this pause occasioned by COVID19 pandemic, it is imperative to understand probe and 
expand the ongoing debate on the causal link between the tourism-led growth hypothesis, energy consumption (renewable and nonrenewable energy use), etc., and the environment, especially the greenhouse gas (GHG) emission as it relates to sub-Saharan Africa which so far is less researched. It is useful to find out if there is any positive correlation and or cointegration between the TLGH, the type of energy use, and environmental pollution in Africa.

In light of the above, as noted by Adedoyin and Bekun (2020) and the World Trade Organization (2018), the tourism industry in the last few decades that accounted for $8 \%$ of the global $\mathrm{CO}_{2}$ emission had overtaken the construction industry to become one of the largest environmental polluters in the world as of 2019. Thus, the causal link between tourism industry, energy use, and GHG emission was established in most of the EU-28 countries between 1995 and 2014 by Balsalobre-Lorente \& Leitão (2020), but the increased use of renewable energy in some EU countries reduces the environmental impact. Findings also revealed that economic advancement in production technology, knowledge and skill in highly developed economies, alongside right economic, energy, and environmental policies are useful tools in curbing environmental pollution and climate change while still enjoying the economic benefits of tourism activities (Adedoyin et.al. 2021a, 2021b). Shaheen et al. (2019) also confirmed the correlation between an increase in foreign direct investment (FDI) as a result of tourism, energy use, and $\mathrm{CO}_{2}$ emission, and Ozpolat et al. (2021) tourism and $\mathrm{CO}_{2}$ emission, in a panel of top 10 tourisminduced economies. The authors reaffirmed that there is a direct increase in energy consumption as international tourism arrival increases, and consequently, a direct negative impact on the environment. Another investigation by Adedoyin et.al. (2020a, 2020b), in a panel involving the BRICS states, revealed the linkage between coal rent, economic growth, and environmental pollution, while Ozturk (2016) and Aslan et al. (2021) probed the connection among tourism, energy consumption, economic growth, and environment in a panel of 34 developed and developing countries in Europe including Turkey and Russia, and a panel of the Mediterranean countries, respectively.

Meanwhile, findings on a few investigations directly on sub-Saharan Africa that factored in other variables other than tourism and/or energy use also revealed the causality between GDP and the environmental pollution. Some of the available pieces of evidence that excluded tourism in their variables often focus either on all or on some other variables such as FDI, energy use, and $\mathrm{CO}_{2}$ emission or environmental pollution in general. Example includes Zaidi \& Saidi (2018) on health expenditure, economic growth, and environmental pollution, Bataka (2020) on globalization and environmental pollution, Hanif (2018) on economic development, fossil fuel and clean energy intake, and urban settlement on carbon emissions. Others that alluded to these findings are Ssali et al. (2019) ecological emission, economic development, energy utilization, and investment from oversees, and Mitchell et al. (2019) pollutant emissions from improved cook stoves of the type used in sub-Saharan Africa. Hanif (2018), for instance, argued that Madagascar, Nigeria, Mauritius, Ghana, Uganda, Cameroon, and particularly South Africa are among the highly ranked developing countries in relation to pollution and $\mathrm{CO}_{2}$ and GHG emissions in subSaharan Africa. Findings further revealed that this increase in environmental pollution is the cause of several devastating biological damages, by implication leading to about half a million death on yearly basis in sub-Saharan Africa according to World Health Organization (2016). Simultaneously, the available evidence, however, suggested both positive and negative correlation and or cointegration between $\mathrm{CO}_{2}$ and GHG emissions and other environmental pollutions, and energy consumption, GDP, FDI, and TLGH (Bataka, 2020; Ssali et al., 2019; Zaidi, \& Saidi, 2018).

Apparently, there is a dearth of panel studies so far with particular attention to SSA on environmental pollution that incorporates the causal link between it and tourism, economic growth, and energy use variables. Among the few available is Lee \& Brahmasrene (2016); the authors probed the tourism effects on the environment and economic sustainability of sub-Saharan Africa, yet this does not include urbanization as a variable. That notwithstanding, the authors further analyzed the topic from the perspectives of oilproducing and non-oil-producing nations on the continent. Their findings indicated a highly significant direct impact of tourism and energy use on economic growth, while it concurrently suggested that tourism, energy use, and economic growth have positive and highly significant impact on carbon emissions in countries in the panel. Furthermore, the Lee \& Brahmasrene posit that other variables but not tourism have effect on environmental pollution in oil-producing countries in sub-Saharan Africa, whereas in non-oil-producing economies, it is tourism and energy use and not economic growth that is implicated in $\mathrm{CO}_{2}$. The very recent one is a separate panel of four North African countries of Egypt, Morocco, Tunisia, and Algeria by El Menyari (2021); tourism was discovered to have no negative impact on environmental pollution in the panel countries, whereas electricity consumption does, indicating that the main source of electricity is unclean and nonrenewable sources in the countries are investigated.

Based on the foregoing, there is a need to further probe the cointegration, causality, and correlation between tourism, GDP, energy use, and carbon emission including urbanization, in a panel of tourism-induced economies in sub-Saharan Africa over a period of time. Therefore, to the best of the authors' knowledge, this study is the first one to incorporate GDP, energy use (renewable and fossil fuel sources), oil-producing and non-oil-producing countries, and 
urbanization into the investigation of the impact of tourism industry on the environment, especially on carbon dioxide and GHG emissions in a panel study on SSA context. Notably, according to Yusuf, 2016 and UNWTO 2020, the top tourist destinations with the highest tourist receipts in Africa are Egypt, South Africa, and Morocco; the others are Kenya, Gambia, Tunisia, and Namibia. However, for whatever reasons, Egypt and Tunisia are not regarded by the international community as part of SSA; rather, they are referred to as North African countries. Nonetheless, for the purpose of this study, these three countries are not only some of the top tourism destinations in Africa, they are also oil-producing countries; hence, they fit into this panel and are therefore included in this investigation. Other countries with reasonable tourism receipts and available data, either they are oil or non-oil-producing nations including Nigeria, Botswana, Ethiopia, Ghana, Mauritius, Senegal, Cameroon, Mauritania, Tanzania, etc., are also included in this panel study.

Sequel to the above, this study intends to probe the following hypotheses: H1: Does tourism induce environmental pollution in Africa? H2: Does tourism and energy use impact differently on pollution in oil-producing countries and non-oil-producing nations in Africa? H3: Do tourism and renewable energy sources indicate cleaner environment in non-oil-producing SSA countries? The next segment in this paper presents and discourses the methods and econometrics and various tests adopted to probe, analyze, and present this investigation.

Hence, given the overwhelming mix of evidence in the literature, understanding the significant factors that affect environmental degradation in a rapid era of tourism is considered essential. As such, this study provides a clearer empirical analysis of the subject matter within the contest of the sub-Saharan Africa economies. Moreover, this study is divided into three sections, i.e., oil countries, non-oil countries, and combination of both oil and non-oil countries.

\section{Methodology, Model, and Data}

\section{Methodology}

To identify the right analytical technique(s) to employ, the authors used the cross section dependency (CD) test. The outcome from the CD test helps in either going for the first-generation or second-generation panel data econometric technique. The analysis will be bias, meaningless, and inconsistent if CD test is not carried out (Dong et al. 2018; Nathaniel et al., 2020). To make sure the mentioned problems do not occur, the authors employed three $\mathrm{CD}$ tests which are the Pesaran (2007) CD test, the Pesaran (2015) scaled LM test, and Breusch-Pagan (1980) LM test for the sake of robustness check. More attention was placed on the Pesaran (2007) scaled CD test and Breusch-Pagan (1980) LM because of how our dataset is shown, i.e., the cross sections $(\mathrm{N})$ number figure is larger than that of the time frame (T). The CD test equation is shown in Eq. 1:

$\mathrm{CD}=\left(\frac{T N(N-1)^{\frac{1}{2}-P}}{2}\right)$

However, from Eq. (3), $\mathrm{P}=\left(\frac{2}{N(N-1)}\right) \sum_{i=1}^{N-1} \sum_{j=i+1}^{N} P i j$, where $P i j$ is the pairwise cross-sectional correlation coefficient of the residual from the ADF regression. $\mathrm{T}$ and $\mathrm{N}$ are the sample and panel scope separately.

\section{Panel stationarity technique}

The proof of CD make in the estimation brings out inefficiency in the first-generation stationarity technique (e.g., Im et al., 2003). Therefore, the authors employed a second-generation stationarity technique (CIPS) to solve the problem of inefficiency in the estimation. From the Pesaran (2007), the CIPS stationary test estimation is shown as

$\Delta \mathrm{Y}_{\mathrm{it}}=\Delta \varphi_{\mathrm{it}}+\beta_{\mathrm{i}} \mathrm{X}_{\mathrm{it}-1}+\rho_{\mathrm{iT}}+\sum_{\mathrm{j}=1}^{\mathrm{n}} \theta \mathrm{ij} \Delta \mathrm{X}_{\mathrm{i}, \mathrm{t}-\mathrm{j}}+\varepsilon_{\mathrm{it}}$

Thus, $\varphi$ it, xit, $\Delta, \mathrm{T}$, as well as $\varepsilon$ it denote the intercept, analysis factors, variance operator, time span, as well as disturbance term correspondingly. A second-generation cointegration test is performed in the proximity of first differences stationary variables, to assess the long-run effects of the factors under consideration.

\section{Panel cointegration estimation}

The findings are related to the Westerlund (2007) experiment to obtain proof of cointegration between the parameters. The error rectification method (ECM) of the estimation is shown as

$\Delta \mathrm{y}_{\mathrm{it}}=\delta_{\mathrm{i}} \mathrm{d}_{\mathrm{t}}+\varphi_{\mathrm{i}} \mathrm{y}_{\mathrm{it}-1}+\lambda_{\mathrm{i}} \mathrm{x}_{\mathrm{it}-1}+\sum_{j=1}^{p i} \phi_{\mathrm{ij}} \Delta \mathrm{y}_{\mathrm{it}-\mathrm{j}}+\sum_{j=0}^{p i} \gamma_{\mathrm{ij}} \Delta \mathrm{x}_{\mathrm{it}-\mathrm{j}}+\mathrm{e}_{\mathrm{it}}$

Thus, $\delta \mathrm{t}=(\delta \mathrm{i} 1, \delta \mathrm{i} 2)^{\prime}, \mathrm{dt}=(1, \mathrm{t})^{\prime}$, and $\phi$ are the vector of parameters, deterministic mechanisms, and the error correction parameter correspondingly. To identify cointegration existence, four tests were carried out. These four tests were built on the OLS technique of $\phi i$ in Eq. 3. Group mean statistics was made up of two out of the four estimations and shown as

$\mathbf{G} \boldsymbol{\tau}=\frac{1}{N} \sum_{i=1}^{N}=\frac{\wedge^{\wedge} \propto i}{S E(\wedge \propto i)}$ and $\mathrm{G} \alpha=\frac{1}{N} \sum_{i=1}^{N} \frac{T^{\wedge} \propto i}{\wedge^{\prime} \propto i(1)}$

Thus, ${ }^{\wedge} \propto i$ is denoted by $S E\left({ }^{\wedge} \propto i\right)$ as the standard error. The semiparametric kernel technique of $\propto i(1)$ is ${ }^{\wedge} \propto i(1)$. 
Two of the four remaining panel mean estimations proof that the entire panel is cointegrated as shown as follows:

$\mathbf{P} \tau=\frac{\wedge}{S E(\propto i)}$ and $P \alpha=\mathrm{T} 1 \alpha^{\wedge}$

\section{Ordinary Least Square (OLS) and Quantile Regression (QR)}

The analysis uses the technique for OLS and QR. The existence of cointegration assesses a long-term connection utilizing the OLS econometrically rational. They use the OLS with standard errors made by Driscoll and Kraay (1998). This method allows (1) heteroscedasticity, (2) serial interaction, and (3) cross-sectional dependency to be considered. Nevertheless, the QR was the chosen statistical tool based on its superior to the OLS for different reasons. The standard circulation as well as the zero mean approval of the OLS error concept is rather unrealistic, since there may be multiple distribution models for socioeconomic measures (De Silva et al. 2016). The QR reinforces this deficit (Salman et al. 2019; Nathaniel et al., 2020). The methodology (QR) does not presume the function of the period (Zhu et al. 2016a, 2016b). In the case of outliers (Bera et al. 2016), forecasts remain robust. No predictions for distribution (Sherwood and Wang, 2016) have been made. The technique for $\mathrm{QR}$ is shown as

Quant $_{\theta}(\mathrm{yi} / \mathrm{xi})=\mathrm{x} \beta_{\theta}+\mu_{\theta}, 0 \mathrm{~b} \theta 1$

where $\mathrm{x}$ is the exogenous factors, while $\mathrm{y}$ is the endogenous factors. The equilibrium place and disruption word of the explicit vector are $\theta$ th and $\mu$ simultaneously. We use the contingent quantile regression that explores the effect of the regressors to be used in our econometric analysis on the foundation of the preliminary factors values. In the past, the QR technology was utilized in Hübler (2017), Xu \& Lin (2018), Nathaniel et al. (2020), and other studies.

\section{Model}

The STIRPAT structure is the foundation of this analysis. The STIRPAT hypothesis notes that the destruction of the ecosystem is both economic and social.

$I_{t}=\vartheta_{0} P_{t}^{\xi 1} A_{t}^{\xi 2} T_{t}^{\xi 3} \mu_{t}$

From Eq. 5, I is a pointer of ecological deprivation, while $\mathrm{P}, \mathrm{A}$, and $\mathrm{T}$ represent inhabitants, wealth, and innovation correspondingly. $\varphi 1-\varphi 3$ as well as $\mu$ are the factor evaluators and the error term correspondingly. T may be broken down based on the purpose of the study (Bello et al. 2018; Anser 2019; Nathaniel et al. 2020). Based on the analysis of Solarin and Al-Mulali studies (2018) and Nathaniel et al. (2020), I, in this analysis, is identified as environmental factors as stated earlier. From a different perspective, $\mathrm{P}$ and $\mathrm{A}$ are denoted by economic sustainability and tourist arrival, respectively. Based on the work of Gyamfi et al. 2021b, 2021c as well as Bamidele et al. 2021, the authors then adopted gross domestic product (GDP), foreign direct investment (FDI), renewable energy (REC), non-renewable energy (NREC), and urbanization (UB) as a proxy $\mathrm{T}$. The extended layout is shown as

$\mathrm{I}_{2 \mathrm{t}}=\vartheta_{\mathrm{o}} \mathrm{TA}_{\mathrm{t}}^{\xi 1} \mathrm{FDI}_{\mathrm{t}}^{\xi 2} \mathrm{GDP}_{\mathrm{t}}^{\xi 3} \mathrm{REC}_{\mathrm{t}}^{\xi 4} \mathrm{NREC}_{\mathrm{t}}^{\xi 5} \mathrm{UB}_{\mathrm{t}}^{\xi 6} \mu_{\mathrm{t}}$

By taking the logarithm of each of the variables, the formula is further formulated as

$\operatorname{lnI} \mathrm{t}_{\mathrm{t}}=\vartheta_{\mathrm{o}} \xi_{1} \mathrm{TA}_{\mathrm{t}}+\xi_{2} \mathrm{FDI}_{\mathrm{t}}+\xi_{3} \mathrm{LnGDP}_{\mathrm{t}}+\xi_{4} \mathrm{LnREC}_{\mathrm{t}}+\xi_{5} \mathrm{LnNREC}_{\mathrm{t}}+\xi_{6} \mathrm{LnUB}_{\mathrm{t}}+\mu_{\mathrm{t}}$

where TA, FDI, GDP, REC, NREC, and UB denote tourist arrival, foreign direct investment, economic growth, renewable energy consumption, non-renewable energy consumption, and urbanization. I, on the other hand, represents the environmental indicator used in this analysis and, thus, $\mathrm{CO}_{2}$ emission. To analysis the impact of TA, FDI, GDP, REC, NREC, and UB on I at the selected quantile level, the authors formulated Eq. (8), which is shown as

$\mathrm{Q}_{\tau}\left(\mathrm{LnCO}_{2}\right)=\vartheta_{\tau}+\xi_{1 \tau} \mathrm{TA}_{\mathrm{it}}+\xi_{2 \tau} \mathrm{FDI}_{\mathrm{it}}+\xi_{3 \tau} \mathrm{LnGDP}_{\mathrm{t}}+\xi_{4 \tau} \mathrm{LnREC}_{\mathrm{it}}+\xi_{5 \tau} \mathrm{LnNREC}_{\mathrm{it}}+\xi_{6} \mathrm{LnUBt}+\mu_{\mathrm{t}}$

whereas the remaining variables maintain their original description, $\mathrm{CO}_{2}$ represents $\mathrm{CO}_{2}$ emission. For the explicative variables, the reference point is $\tau$. Q $\tau$ corresponds to the $\tau$ th distributional point regression analysis that can be determined using the formulae in Eq. (9):
$\mathrm{Q}_{\tau}=\operatorname{argmin} \sum_{k=1}^{q} \sum_{t=1}^{T} \sum_{i=1}^{N}\left(\left|\mathrm{y}_{\mathrm{it}}-\alpha_{\mathrm{i}}-\mathrm{x}_{\mathrm{it}} \mathrm{Q}_{\tau}\right| 1 \mathrm{it}\right)$

where $\mathrm{q}, \mathrm{T}, \mathrm{N}$, and $\mathrm{H}_{\mathrm{it}}$ stand for the number of quantiles, years, cross sections, and weight of the ith country in the ith year, respectively. The sub-Saharan Africa countries were 
Table 1 Description of Variables

\begin{tabular}{llll}
\hline Name of Indicator & Abbreviation & Proxy/Scale of Measurement & Source \\
\hline Carbon dioxide emissions per capita & $\mathrm{CO}_{2}$ & Measured in metric tonnes & WDI \\
Income & GDP & $\begin{array}{l}\text { It is proxied by the gross domestic product } \\
\text { per capita (2010 Constant USD) }\end{array}$ & WDI \\
Tourist Arrivals & TA & Number of arrivals & WDI \\
Foreign direct investment & FDI & \% of real GDP & WDI \\
Fossil fuel & NREC & Fossil fuel energy consumption (\% of total) & WDI \\
Renewable energy & REC & Renewable energy consumption (\% of total & WDI \\
& & final energy consumption) & \\
Urbanization & UB & Urban population growth & \\
\hline
\end{tabular}

Authors compilation for this analysis and were divided into twofold, i.e., 14 oilproducing and 27 non-oil-producing countries summing up to a total of 41 (list of countries in the Appendix Table 10) from the period of 1995 to 2016 . The period of time for this analysis was based on the availability of data. The time period was sorely based on data availability. All data utilized in this analysis were obtained from World Development Indicators (WDI, 2020). All variables expect FDI were transformed to logarithm in this analysis. As Table 1 gives a summary of the description of the variables, further discussion on the variables of interest is made. The methodological sequence is appended in Fig. 1

Carbon dioxide emissions per capita $\left(\mathrm{CO}_{2}\right)$ This variable is used as the dependent variable in the model as the proxy for the environment. The unit of measurement of carbon dioxide emissions is metric tons per capita. The apriority expectation of this variable can either be positive or negative. A positive change in carbon dioxide emissions would suggest environmental degradation whereas the negative change indicates environmental sustainability. Carbon dioxide is takes the largest percentage among the greenhouse gas emission components at about 70 percent. This justifies the reason of chosen carbon dioxide emissions as environment indicator. Also, for a vivid and insightful study of this particular topic, it is vital to adopt carbon dioxide emission as a measure of environment.

Income (GDP) This variable is used as an explanatory variable to proxy for economic growth across the countries under consideration. The income values are transformed from the local currencies to the dollars of the USA by applying the current exchange rate. A positive change in the income values of the sub-Saharan Africa economies would indicate economic growth. In extension of the instance of GDP as the total value of goods and services produced in a country in a given year, the activities that are involved the totality of GDP impact the environmental performance of any country.

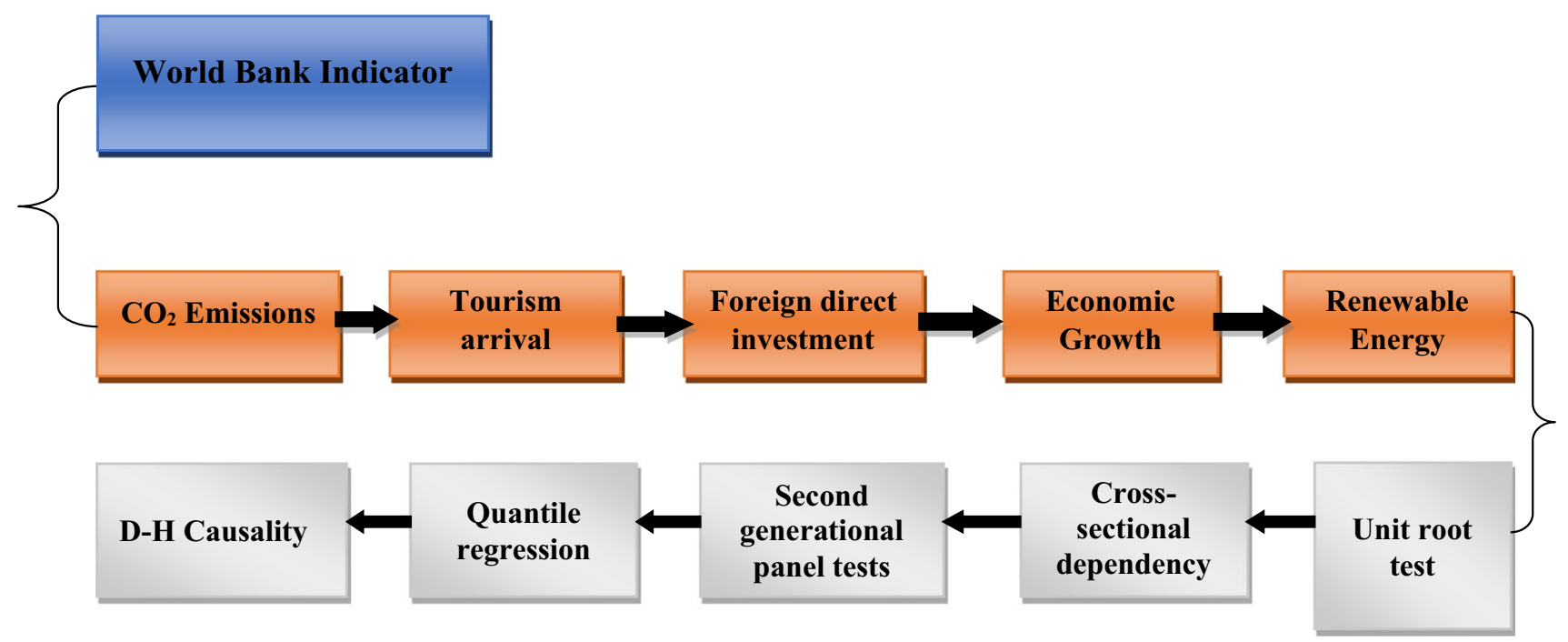

Fig. 1 Analysis Flowchart 
Theories (such as EKC) have revealed the pattern of relationship that exists between economic growth (GDP) and the environment. The patterns could be U-shape. Inverted $\mathrm{U}$-shape or even $\mathrm{N}$-shape points toward what happens to environmental performance at any given stage of economic growth. This justifies why we chose economic growth (GDP) as among the explanatory variables.

Tourist Arrivals (TA) This is another independent variable that is proxied for tourism. This tourism variable measures the number of international tourists who visit and stay within the confines of tourist establishments. A positive change in tourist arrivals signifies gains from tourism, while a negative change indicates that tourism has no significant benefit. The tourism sector and its management involves utilization of energy to run the industry both in transportation of the tourists and in entertainment of the tourists through hotels and holidays management. These activities involve high utilization of energy which impact the environment (mostly negative due to fossil fuels). This is why the tourism arrival is considered essential to this study.

Fossil Fuel (NREC) This is one of the explanatory variables in the model that is proxied for a non-renewable source of energy as well as a control variable in the model. Fossil fuel of energy consumption is a composition of the following products: natural gas, oil, coal, and petroleum. A positive change in the fossil fuel value with regards to a priori expectation would imply a detrimental effect on the environmental sustainability of the panel countries. The economic activities of sub-Saharan countries are highly dependent on fossil fuels energy utilization which has serious environmental implication.

Renewable energy (REC) This is one of the explanatory variables in the model that is proxied for a renewable source of energy as well as a control variable in the model. Renewable energy consumption is a composition of all the renewables, namely solar, wind, hydro, tidal, geothermal, and biomass energies. A shift from fossil fuels to alternative source of energy (renewable) tends to reduce the negative implication of fossil fuels to the environmental performance. Utilizing renewable energy source as one of the explanatory exposes the effect of renewable energy on economic and environmental performance of the region.

Foreign Direct Investment (FDI) This variable is used as an explanatory variable to proxy for investment from oversees into the countries under consideration. Foreign direct investment is the net inflows of investment to acquire a lasting management interest (10 percent or more of voting stock) in an enterprise operating in an economy other than that of the investor. A positive change in the FDI values of the
sub-Saharan Africa economies would indicate economic pollutant Hallo, while a negative will indicate pollutant heaven hypothesis $(\mathrm{PHH})$. Due to less rigid laws and regulations of the region against the foreign investors, the foreign investors tend to engage on some economics practices (such as engaging carbon-intensive mechanism through adopting fossil fuel energy source) that are unfriendly to the environmental performance of the region. It is vital to capture the impact of the activities of foreign investors through FDI.

Urbanization (UB) This variable is used as an explanatory variable to proxy movement from rural areas to the urban areas within the countries under consideration. Most economic activities (industrial and manufacturing, social gathering, and other functions) take place in the cities with higher population than rural areas, hence the reason for choosing the urbanization as among the explanatory variables.

\section{Empirical results and discussion}

This section presents the interpretation of result and discussion of empirical findings. We set off with preliminary analysis of basic summary statistics and correlation analysis. Table 2 provides both oil and non-oil blocs. The results show that most series under investigation for combined blocs are negatively skewed and all series show heavy tail as reported by Kurtosis with magnitude more than 2 . Subsequently, the pairwise correlation analysis shows more glimpse into the series a nature of relationship as reported in Table 3. The pairwise correlation shows strong statistical relationship between GDP growth and tourism, which gives credence to the tourism-induced GDP growth. However, we also observed FDI-growth relationship. Interestingly, we can see a positive statistical relationship between tourism and economic growth. Similar statistical relationship is observed between FDI and $\mathrm{CO}_{2}$ emission. These relationships between macroeconomic indicators and $\mathrm{CO}_{2}$ emissions are instructive for the government officials in the investigated blocs. It is worthy to note that pairwise analysis is not sufficient to substantiate any claim given the weakness in the test. Thus, this study proceeds to explore more econometrics analysis to explore the relationship between the outlined variables.

Subsequently, this study investigates the effect of common shows among the investigated countries under review as presented in Table 4 . The cross-sectional dependency test is necessary to avoid pitfall of spurious regression and policy guidance by extension. Furthermore, the cross-sectional test support models either first- or second-generational estimators. In our case given, we reject the null hypothesis of no-cross-sectional dependency. We advance with secondgenerational estimator. Table 5 shows both first- and second-generational unit root for the investigated variables. In 
Table 2 Descriptive statistics

\begin{tabular}{|c|c|c|c|c|c|c|c|}
\hline & $\mathrm{LnCO}_{2}$ & LnTA & FDI & LnGDP & LnNREC & LnREC & LnUB \\
\hline & \multicolumn{7}{|c|}{ NON-OIL COUNTRIES } \\
\hline Mean & -1.7257 & 10.947 & 0.1128 & 6.4913 & 1.0165 & 4.2812 & 3.28729 \\
\hline Median & -1.7369 & 11.904 & 0.4957 & 6.4180 & 0.0000 & 4.4045 & 3.3961 \\
\hline Maximum & 0.4575 & 14.734 & 4.6379 & 8.1696 & 4.0103 & 4.5823 & 4.1710 \\
\hline Minimum & -3.8674 & 0.566 & -13.183 & 0.0000 & 0.0000 & 0.0000 & 1.6893 \\
\hline Std. Dev & 0.9144 & 3.519 & 1.9893 & 0.6679 & 1.3907 & 0.3669 & 0.4783 \\
\hline Skewness & 0.3222 & -1.825 & -2.2817 & -2.1278 & 0.8300 & -4.8498 & -0.6584 \\
\hline \multirow[t]{2}{*}{ Kurtosis } & $2.3873 a$ & $5.386 \mathrm{a}$ & $13.656 a$ & $24.537 \mathrm{a}$ & $2.0201 \mathrm{a}$ & $49.571 \mathrm{a}$ & $2.8821 \mathrm{a}$ \\
\hline & \multicolumn{7}{|c|}{ OIL COUNTRIES } \\
\hline Mean & -0.1553 & 13.138 & 0.7224 & 7.7872 & 3.2440 & 3.2444 & 15.667 \\
\hline Median & -0.3198 & 12.953 & 0.7331 & 7.7206 & 3.4687 & 4.1701 & 15.816 \\
\hline Maximum & 2.4162 & 16.458 & 5.0865 & 9.9297 & 4.6049 & 4.5880 & 18.321 \\
\hline Minimum & -4.7725 & 9.104 & -13.121 & 6.1361 & 0.0000 & -2.8309 & 11.888 \\
\hline Std. Dev & 1.3697 & 1.845 & 1.8733 & 0.8577 & 1.4262 & 1.6486 & 1.2894 \\
\hline Skewness & -0.0736 & 0.091 & -3.2383 & 0.4961 & -1.3223 & -1.4882 & -0.5869 \\
\hline \multirow[t]{2}{*}{ Kurtosis } & $2.3945 b$ & $1.845 \mathrm{a}$ & $24.388 \mathrm{a}$ & $2.6416 \mathrm{a}$ & $3.8206 \mathrm{a}$ & $4.4491 \mathrm{a}$ & $3.1476 \mathrm{a}$ \\
\hline & \multicolumn{7}{|c|}{ COMBINATION OF OIL AND NON-OIL COUNTRIES } \\
\hline Mean & -1.1903 & 11.690 & 0.3346 & 6.9331 & 1.7759 & 3.9278 & 7.5079 \\
\hline Median & -1.4179 & 12.284 & 0.6778 & 6.8012 & 1.8821 & 4.3634 & 3.6523 \\
\hline Maximum & 2.4162 & 16.458 & 5.0865 & 9.9297 & 4.6049 & 4.5880 & 18.321 \\
\hline Minimum & -4.7725 & 0.566 & -13.183 & 0.0000 & 0.0000 & -2.8309 & 1.6893 \\
\hline Std. Dev & 1.3206 & 3.217 & 1.9748 & 0.9602 & 1.7556 & 1.1205 & 5.9318 \\
\hline Skewness & 0.6397 & -1.942 & -2.5185 & 0.1092 & 0.2039 & -3.0626 & 0.7058 \\
\hline Kurtosis & $2.9099 a$ & 6.993 & $16.047 \mathrm{a}$ & $7.5915 \mathrm{a}$ & $1.4097 \mathrm{a}$ & $12.994 \mathrm{a}$ & $1.5796 \mathrm{a}$ \\
\hline
\end{tabular}

$\mathrm{a}=0.01, \mathrm{~b}=0.05, \mathrm{c}=0.10$

Table 6, we present the Westerlund cointegration test. The results show long-run equilibrium (cointegration) relationship between our study variables over the sampled period for both oil and non-oil countries in sub-Saharan countries.

\section{Discussions}

After the confirmation of the existence of cointegration in all the groups, which points toward a long-run relationship among the selected variables, we proceed with the explanation of the findings from the regressions as shown in Table 7. The explanation is based on both ordinary least square and quantile regression for a robust check, but our emphasis is on the outcome of quantile regression. From the non-oil countries group, a positive and statistically significant relationship is found between tourism arrival and carbon emission (environmental degradation) both in OLS and all the quantiles except the median $\left(50^{\text {th }}\right.$ quantile $)$ that shows insignificant positive (negative relationship) influence of tourism arrival on environment quality which may be the increasing number of tourists within these countries that affect transportation which is the biggest component that increases tourism-emission mix. Tourism arrival exerts a stronger negative influence on the environment quality in the $75^{\text {th }}-90^{\text {th }}$ quantile with the largest coefficient $(0.0923)$. This shows that a 1 percent point increase in tourism arrival will cause a 0.0923 percent point increase in carbon emission (decrease in environment quality) across the non-oil countries. This suggests that the presence of the tourists and their activities in the non-oil sub-Saharan Africa is unfriendly to the environment performance in the region. An insight is given toward the possibility of reversing this trend from the finding from the median $\left(50^{\text {th }}\right.$ quantile). This shows that an increase in tourism arrival has the possibility of remedying the environmental degradation. This could be possible with strict implementing and monitoring of environmental regulations void of corruption by the government officials in the affected region. This supports the finding by Udemba (2019); Sarpong et al. (2020); Gyamfi et al. (2021a, 2021b, 2021c, 2021d, 2021e), and Bamidele et al. (2021). A statistically significant positive relationship is found between FDI and carbon emission both in OLS and across the entire quantiles except the $90^{\text {th }}$ quantile that shows a negative relationship with emission. This depicts a negative impact of foreign investors on the environment management of the non-oil region of sub-Saharan Africa. Basing on the quantile $\left(5^{\text {th }}\right)$ with the highest influence of carbon emission with regards 
Table 3 Correlation matrix

\begin{tabular}{|c|c|c|c|c|c|c|c|}
\hline & $\mathrm{LnCO}_{2}$ & LnTA & FDI & LnGDP & LnNREC & LnREC & LnUB \\
\hline & \multicolumn{7}{|c|}{ NON-OIL COUNTRIES } \\
\hline $\mathrm{LnCO}_{2}$ & \multicolumn{7}{|l|}{1.0000} \\
\hline LnTA & $0.401 \mathrm{a}$ & \multicolumn{6}{|l|}{1.0000} \\
\hline LnFDI & $0.1390 \mathrm{a}$ & $-0.154 a$ & 1.0000 & & & & \\
\hline LnGDP & $0.6477 \mathrm{a}$ & $0.149 \mathrm{a}$ & $0.1456 \mathrm{a}$ & \multicolumn{4}{|l|}{1.0000} \\
\hline LnNREC & $0.2841 \mathrm{a}$ & $0.535 \mathrm{a}$ & -0.0131 & $0.1226 \mathrm{a}$ & \multicolumn{3}{|l|}{1.0000} \\
\hline LnREC & $-0.6057 \mathrm{a}$ & $-0.372 \mathrm{a}$ & $-0.0839 b$ & $-0.2385 a$ & 0.0499 & \multicolumn{2}{|l|}{1.0000} \\
\hline \multirow[t]{2}{*}{ LnUB } & $0.4598 \mathrm{a}$ & $0.570 \mathrm{a}$ & $0.3203 \mathrm{a}$ & $0.3939 a$ & $0.1345 \mathrm{a}$ & $-0.3210 \mathrm{a}$ & 1.0000 \\
\hline & \multicolumn{7}{|c|}{ OIL COUNTRIES } \\
\hline $\mathrm{LnCO}_{2}$ & \multicolumn{7}{|l|}{1.0000} \\
\hline LnTA & $0.101 \mathrm{~b}$ & \multicolumn{6}{|l|}{1.0000} \\
\hline LnFDI & 0.0442 & -0.023 & \multicolumn{5}{|l|}{1.0000} \\
\hline LnGDP & $0.8924 a$ & -0.009 & $0.1239 b$ & \multicolumn{4}{|l|}{1.0000} \\
\hline LnNREC & $0.4783 a$ & $0.408 \mathrm{a}$ & $-0.1553 a$ & $0.2450 \mathrm{a}$ & \multicolumn{3}{|l|}{1.0000} \\
\hline LnREC & $-0.6918 \mathrm{a}$ & $0.233 \mathrm{a}$ & $0.1513 a$ & $-0.4968 \mathrm{a}$ & $-0.4574 a$ & \multicolumn{2}{|l|}{1.0000} \\
\hline \multirow[t]{2}{*}{ LnUB } & 0.0100 & $0.006 \mathrm{a}$ & $-0.2390 \mathrm{a}$ & $-0.2514 \mathrm{a}$ & $0.6114 \mathrm{a}$ & $-0.2249 a$ & 1.0000 \\
\hline & \multicolumn{7}{|c|}{ COMBINATION OF OIL AND NON-OIL COUNTRIES } \\
\hline $\mathrm{LnCO}_{2}$ & \multicolumn{7}{|l|}{1.0000} \\
\hline LnTA & $0.093 \mathrm{a}$ & \multicolumn{6}{|l|}{1.0000} \\
\hline LnFDI & $0.1647 \mathrm{a}$ & 0.054 & \multicolumn{5}{|l|}{1.0000} \\
\hline LnGDP & $0.8478 \mathrm{a}$ & $0.100 \mathrm{a}$ & $0.2064 \mathrm{a}$ & \multicolumn{4}{|l|}{1.0000} \\
\hline LnNREC & $0.5791 \mathrm{a}$ & $0.201 \mathrm{a}$ & 0.0410 & $0.4900 \mathrm{a}$ & \multicolumn{3}{|l|}{1.0000} \\
\hline LnREC & $-0.6972 \mathrm{a}$ & $-0.140 \mathrm{a}$ & -0.0077 & $-0.5388 \mathrm{a}$ & $-0.4415 \mathrm{a}$ & \multicolumn{2}{|l|}{1.0000} \\
\hline LnUB & $0.5758 \mathrm{a}$ & $0.101 \mathrm{a}$ & $0.1528 \mathrm{a}$ & $0.6313 \mathrm{a}$ & $0.6379 \mathrm{a}$ & $-0.4643 \mathrm{a}$ & 1.0000 \\
\hline
\end{tabular}

$\mathrm{a}=0.01, \mathrm{~b}=0.05, \mathrm{c}=0.10$

Table 4 Cross-sectional dependency test results for combined countries

\begin{tabular}{llll}
\hline & Pesaran(2007) CD Test & Pesaran(2015) LM Test & Breusch-Pagan LM \\
\hline $\mathrm{LnCO}_{2}=\mathrm{f}(\mathrm{LnTA}$, LnGDP, FDI, LnREC, LnNREC, LnUB) & $-1.765 \mathrm{c}$ & $0.671 \mathrm{a}$ & $6597.70 \mathrm{a}$ \\
\hline
\end{tabular}

$\mathrm{a}=0.01, \mathrm{~b}=0.05, \mathrm{c}=0.10$

to its coefficient, a percent point increase in FDI will lead to 0.058 percent increase in degradation of non-oil sub-Saharan African countries' environments except quantile $\left(90^{\text {th }}\right)$ which shows a negative significant relationship at 0.0510 percent which might result in that at this level, the policymakers have taken note of the harm FDI that is causing to the environment, resulting in implementing strong regulations and policy to control. The other outcomes indicate that foreign investors are flaunting the environmental regulations in the various countries of their economic activities base. FDI can either be positive or negative in sustainable development as it concerns environmental effects. The controlling and determinant force behind its environmental and economic impact is the effectiveness of government officials to implement and monitor the adherence to environmental laws. It is a well-known fact that advanced countries are keen and strict with environmental regulations and this does not augur well with some of the indigenous investors who will now consider developing economies as a substitute in performing their economic activities under the auspices of globalization and economic integration Most developing countries including sub-Saharan African countries are known with laxity in implementing sustainable policies, and this has resulted in foreign investors exploring the loopholes in the laws to the detriment of the environmental quality. This supports the findings by Gyamfi et al. 2021d, Udemba, 2019, Sarkodie and Strezov, 2019, Zhang and Zhang 2018, and Balsalobre-Lorente et al., 2018. A positive relationship is found between economic growth, non-renewable energy consumption, urbanization, and carbon emission. Economic growth exerts intense negative influence on the environment of the non-oil region in the $75^{\text {th }}-90^{\text {th }}$ quantiles at 0.77 and 0.92 percent point, respectively, while fossil fuels and urbanization exert negative stronger influence on the environment 
Table 5 Panel IPS and CIPS unit root test

\begin{tabular}{|c|c|c|c|c|c|c|c|c|}
\hline \multirow[t]{3}{*}{ Variables } & \multicolumn{4}{|c|}{ IPS (Im et al,. 2003) } & \multicolumn{4}{|c|}{ CIPS (Pesaran 2007) } \\
\hline & \multicolumn{2}{|l|}{ Intercept } & \multicolumn{2}{|c|}{ Intercept and trend } & \multicolumn{2}{|c|}{ Intercept } & \multicolumn{2}{|c|}{ Intercept and trend } \\
\hline & Levels & $1^{\text {st }}$ Diff & Levels & $1^{\text {st }}$ Diff & Levels & $1^{\text {st }}$ Diff & Levels & $1^{\text {st }}$ Diff \\
\hline \multicolumn{9}{|c|}{ NON-OIL COUNTRIES } \\
\hline $\mathrm{LnCO}_{2}$ & -0.8278 & $-5.0009 \mathrm{a}$ & -1.9736 & $-5.1071 \mathrm{a}$ & -1.559 & $-5.054 \mathrm{a}$ & -2.598 & $-5.029 a$ \\
\hline LnTA & -0.9811 & $-5.9257 \mathrm{a}$ & -2.5611 & $-6.5712 \mathrm{a}$ & -2.549 & $-4.979 a$ & -1.3442 & $-5.904 \mathrm{a}$ \\
\hline FDI & $-3.0318 c$ & $-7.0897 \mathrm{a}$ & $-3.8116 b$ & $-7.0793 \mathrm{a}$ & $-3.624 a$ & $-5.482 \mathrm{a}$ & $-3.678 a$ & $-5.904 \mathrm{a}$ \\
\hline LnGDP & -0.8811 & $-4.7004 a$ & $-2.3232 \mathrm{a}$ & $-4.9828 \mathrm{a}$ & -1.686 & $-4.479 a$ & -2.344 & $-4.711 \mathrm{a}$ \\
\hline LnREC & -1.1977 & $-4.9257 \mathrm{a}$ & -2.4811 & $-4.8849 a$ & -1.384 & $-4.593 a$ & -2.403 & $-5.102 \mathrm{a}$ \\
\hline LnNREC & -1.690 & $-3.4373 a$ & -1.730 & $-5.5702 \mathrm{a}$ & -0.652 & $-3.106 a$ & -0.003 & $-2.668 b$ \\
\hline LnUB & -1.1089 & $-2.3391 c$ & -2.6562 & $-4.4946 a$ & -1.868 & $-3.968 \mathrm{a}$ & -1.535 & $-3.278 \mathrm{a}$ \\
\hline \multicolumn{9}{|c|}{ OIL COUNTRIES } \\
\hline $\mathrm{LnCO}_{2}$ & -1.8559 & $-6.5903 a$ & -2.7802 & $-6.6145 a$ & -2.747 & $-5.650 a$ & -2.870 & $-5.835 \mathrm{a}$ \\
\hline FDI & $-3.1065 a$ & $-6.9291 \mathrm{a}$ & $-3.6644 a$ & $-6.9105 a$ & $-3.378 \mathrm{a}$ & $-5.443 \mathrm{a}$ & $-3.580 a$ & $-5.521 \mathrm{a}$ \\
\hline LnTA & -1.520 & $-4.5123 a$ & -2.910 & $-4.5931 \mathrm{a}$ & -2.564 & $-5.329 a$ & -1.138 & $-5.755 a$ \\
\hline LnGDP & -0.5901 & $-4.1620 \mathrm{a}$ & $-2.0336 \mathrm{c}$ & $-4.3376 a$ & -2.508 & $-3.591 \mathrm{a}$ & -2.234 & $-3.886 \mathrm{a}$ \\
\hline LnREC & -0.9674 & $-5.1113 a$ & -0.5798 & $-5.1895 a$ & $-2.492 \mathrm{a}$ & $-4.923 a$ & $-2.737 b$ & $-4.799 a$ \\
\hline LnNREC & -1.820 & $-3.5123 a$ & -1.900 & $-3.4931 \mathrm{a}$ & -1.544 & $-4.309 a$ & -2.238 & $-4.655 a$ \\
\hline LnUB & $-4.9888 \mathrm{a}$ & $-2.4248 \mathrm{a}$ & -0.6076 & $-3.9434 a$ & -2.067 & $-2.104 c$ & -0.989 & $-2.565 b$ \\
\hline \multicolumn{9}{|c|}{ COMBINATION OF OIL AND NON-OIL COUNTRIES } \\
\hline $\mathrm{LnCO}_{2}$ & -1.1783 & $-5.5427 \mathrm{a}$ & -2.2486 & $-5.6210 \mathrm{a}$ & -1.978 & $-5.082 \mathrm{a}$ & -2.695 & $-5.259 \mathrm{a}$ \\
\hline LnTA & -1.291 & $-4.4529 \mathrm{a}$ & -2.710 & $-3.2561 b$ & -1.185 & $-3.679 b$ & -1.655 & $-4.134 \mathrm{a}$ \\
\hline FDI & $-3.0816 a$ & $-7.0562 \mathrm{a}$ & $-3.7605 \mathrm{a}$ & $-7.0482 \mathrm{a}$ & $-3.618 \mathrm{a}$ & $-5.582 \mathrm{a}$ & $-3.749 \mathrm{a}$ & $-5.815 \mathrm{a}$ \\
\hline LnGDP & -2.2245 & $-4.7629 a$ & -0.7819 & $-4.5169 \mathrm{a}$ & -2.047 & $-4.100 \mathrm{a}$ & -2.190 & $-4.258 \mathrm{a}$ \\
\hline LnREC & -1.1192 & $-4.9890 \mathrm{a}$ & -2.5148 & $-4.9887 a$ & $-2.064 c$ & $-4.765 a$ & -2.566 & $-4.697 \mathrm{a}$ \\
\hline LnNREC & -1.690 & $-3.4629 a$ & -1.730 & $-2.2565 b$ & -0.185 & $-1.679 c$ & -0.755 & $-2.120 b$ \\
\hline LnUB & $-3.7498 b$ & $-2.3683 a$ & -3.0950 & $-3.5497 a$ & -2.284 & $-2.238 a$ & -1.638 & $-2.393 b$ \\
\hline
\end{tabular}

$\mathrm{a}=0.01, \mathrm{~b}=0.05, \mathrm{c}=0.10$

\begin{tabular}{|c|c|c|c|c|}
\hline \multirow[b]{2}{*}{ Dependent/models } & \multicolumn{2}{|c|}{ Group Statistics } & \multicolumn{2}{|c|}{ Panel Statistics } \\
\hline & $\mathrm{G} \tau$ & $\mathrm{G} \alpha$ & $\mathrm{P} \tau$ & $\mathrm{P} \alpha$ \\
\hline NON-OIL COUNTRIES & & & & \\
\hline $\begin{array}{l}\mathrm{LnCO}_{2}=\mathrm{f}(\mathrm{LnTA}, \mathrm{FDI}, \mathrm{LnGDP}, \mathrm{LnREC}, \mathrm{LnNREC}, \mathrm{LnUB}) \\
\text { OIL COUNTRIES }\end{array}$ & $-1.267 \mathrm{c}$ & $-3.020 \mathrm{c}$ & $-3.109 \mathrm{a}$ & $-2.797 b$ \\
\hline $\begin{array}{l}\mathrm{LnCO}_{2}=\mathrm{f}(\mathrm{LnTA}, \mathrm{FDI}, \mathrm{LnGDP}, \mathrm{LnREC}, \text { LnNREC, LnUB }) \\
\text { COMBINATION OF OIL AND NON-OIL COUNTRIES }\end{array}$ & $-4.332 \mathrm{a}$ & $-2.336 b$ & $-4.144 \mathrm{a}$ & $-2.449 b$ \\
\hline $\mathrm{LnCO}_{2}=\mathrm{f}(\mathrm{LnTA}, \mathrm{FDI}, \mathrm{LnGDP}, \mathrm{LnREC}, \mathrm{LnNREC}, \mathrm{LnUB})$ & $-3.186 a$ & $-3.077 \mathrm{a}$ & $-6.471 \mathrm{a}$ & $-4.171 b$ \\
\hline
\end{tabular}

$\mathrm{a}=0.01, \mathrm{~b}=0.05, \mathrm{c}=0.10$

Table 6 Westerlund

Cointegration Test

of the non-oil region in the $50^{\text {th }}-75^{\text {th }}(0.1685$ and 0.1588$)$ and $25^{\text {th }}-50^{\text {th }}(0.4469$ and 0.5642$)$ quantiles, respectively. It is important to mention here that urbanization displays a significantly negative relationship with carbon emission in the $90^{\text {th }}$ quantile which is a good story for the non-oil region. This is a good sign that urbanization will impact favorably to the environmental performance. These findings reflect the characteristics of developing economies that depict maximum efforts put in pursuit of economic growth at the expense of environment performance, and massive rural-urban migration that most times leave the urban areas in environmental mess if necessary environmental measures are not taken. These findings support the findings of Bekun et al. 2021a, 2021b, 2021c; Onifade et al. 2021; Udemba, 2019; Bekun et al., 2019; Shahbaz et al., 2010; Shahbaz et al., 2013; and Guangyue and Deyong, 2011. A statistically significant negative relationship is found between renewable energy consumption and carbon emission. This 
Table 7 Ordinal least square (OLS) and Quantile Regression (QR) Result for long-run relationship

\begin{tabular}{|c|c|c|c|c|c|c|}
\hline & OLS & Q.05 & Q.25 & Q.50 & Q.75 & Q.90 \\
\hline \multicolumn{7}{|c|}{ NON-OIL COUNTRIES } \\
\hline LnTA & $0.0217 \mathrm{a}$ & $0.0263 \mathrm{a}$ & $0.0116 b$ & -0.0353 & 0.0157 & $0.0923 \mathrm{a}$ \\
\hline FDI & $0.0343 b$ & $0.0580 \mathrm{~b}$ & $0.0548 \mathrm{c}$ & $0.0140 \mathrm{c}$ & $0.0294 \mathrm{c}$ & $-0.0510 \mathrm{c}$ \\
\hline LnGDP & $0.7637 \mathrm{a}$ & $0.6567 \mathrm{a}$ & $0.5142 \mathrm{a}$ & $0.5993 \mathrm{a}$ & $0.7727 \mathrm{a}$ & $0.9215 \mathrm{a}$ \\
\hline LnREC & $-0.8327 \mathrm{a}$ & $-0.7762 \mathrm{a}$ & $-0.7970 \mathrm{a}$ & $-0.7351 \mathrm{c}$ & $-0.4669 \mathrm{a}$ & $-1.7212 \mathrm{a}$ \\
\hline LnNREC & $0.1355 \mathrm{a}$ & $0.1129 \mathrm{a}$ & $0.1267 \mathrm{a}$ & $0.1685 \mathrm{a}$ & $0.1588 \mathrm{a}$ & $0.0690 \mathrm{a}$ \\
\hline LnUB & $0.2588 \mathrm{a}$ & $0.4469 a$ & $0.5642 \mathrm{a}$ & $0.3975 \mathrm{c}$ & $0.4126 a$ & $-0.3187 \mathrm{a}$ \\
\hline Constant & $-4.4192 \mathrm{a}$ & $-5.1899 \mathrm{a}$ & $-4.1611 \mathrm{a}$ & $-4.0300 \mathrm{a}$ & $-6.1753 a$ & 0.3324 \\
\hline F-Statistic & $289.88 \mathrm{a}$ & & & & & \\
\hline R2/Pesudo-R2 & 0.7477 & 0.5809 & 0.5657 & 0.5601 & 0.5319 & 0.5173 \\
\hline Adj R-square & 0.7451 & & & & & \\
\hline Observation & 594 & 594 & 594 & 594 & 594 & 594 \\
\hline \multicolumn{7}{|c|}{ OIL COUNTRIES } \\
\hline & OLS & Q.05 & Q.25 & Q.50 & Q.75 & Q.90 \\
\hline LnTA & $0.0660 \mathrm{a}$ & $0.0899 \mathrm{c}$ & $0.0864 \mathrm{a}$ & $0.0638 \mathrm{a}$ & $0.0481 \mathrm{a}$ & $0.0363 b$ \\
\hline FDI & $0.0288 \mathrm{c}$ & 0.06504 & $0.0196 \mathrm{c}$ & $0.0120 \mathrm{~b}$ & $0.0429 b$ & $0.0353 c$ \\
\hline LnGDP & $1.1320 \mathrm{a}$ & $1.0199 \mathrm{a}$ & $1.2148 \mathrm{a}$ & $1.1221 \mathrm{a}$ & $1.0613 \mathrm{a}$ & $1.0014 \mathrm{a}$ \\
\hline LnREC & $-0.1373 a$ & $-0.1816 a$ & $-0.0826 a$ & $-0.1319 a$ & $-0.1809 a$ & $-0.1740 \mathrm{a}$ \\
\hline LnNREC & $0.2321 \mathrm{a}$ & $0.1226 \mathrm{c}$ & $0.2538 \mathrm{a}$ & $0.2689 a$ & $0.2415 \mathrm{a}$ & $0.2949 a$ \\
\hline LnUB & $0.0629 b$ & $0.2646 a$ & 0.0414 & $0.0133 \mathrm{c}$ & $0.0186 a$ & $0.0195 \mathrm{c}$ \\
\hline Constant & $-11.2051 \mathrm{a}$ & $-12.930 \mathrm{a}$ & $-12.168 \mathrm{a}$ & $-10.4262 \mathrm{a}$ & $-9.3735 \mathrm{a}$ & $-8.8635 a$ \\
\hline F-Statistic & $820.23 a$ & & & & & \\
\hline $\mathrm{R}^{2} /$ Pseudo- $\mathrm{R}^{2}$ & 0.9424 & 0.7268 & 0.7514 & 0.7872 & 0.7867 & 0.7970 \\
\hline Adj R-square & 0.9412 & & & & & \\
\hline Observation & 308 & 308 & 308 & 308 & 308 & 308 \\
\hline \multicolumn{7}{|c|}{ COMBINATION OF OIL AND NON-OIL COUNTRIES } \\
\hline & OLS & Q.05 & Q.25 & Q.50 & Q.75 & Q.90 \\
\hline LnTA & $-0.0243 b$ & $-0.0555 \mathrm{a}$ & $-0.0279 \mathrm{a}$ & $-0.0147 b$ & 0.0879 & $0.0154 b$ \\
\hline FDI & $0.0057 \mathrm{c}$ & $0.0093 \mathrm{c}$ & $-0.0030 \mathrm{c}$ & $0.0903 b$ & $0.0130 \mathrm{c}$ & $0.0695 b$ \\
\hline LnGDP & $1.0975 \mathrm{a}$ & $1.1009 \mathrm{a}$ & $1.0550 \mathrm{a}$ & $1.0960 \mathrm{a}$ & $1.0749 \mathrm{a}$ & $1.1133 \mathrm{a}$ \\
\hline LnREC & $-0.2359 \mathrm{a}$ & $-0.0238 \mathrm{a}$ & $-0.1656 a$ & $-0.0146 \mathrm{a}$ & $-0.0137 \mathrm{a}$ & $-0.0129 \mathrm{a}$ \\
\hline LnNREC & $0.1620 \mathrm{a}$ & $0.0388 \mathrm{c}$ & $0.0441 b$ & $0.0422 b$ & $0.0500 \mathrm{a}$ & $0.0667 \mathrm{a}$ \\
\hline LnUB & $-0.0310 \mathrm{a}$ & $-0.0350 \mathrm{a}$ & $-0.0203 a$ & $-0.0360 a$ & $-0.0285 a$ & $-0.0477 \mathrm{a}$ \\
\hline Constant & $-7.9453 a$ & $-9.0270 \mathrm{a}$ & $-8.7837 \mathrm{a}$ & $-8.8031 \mathrm{a}$ & $-8.6149 a$ & $-8.6986 a$ \\
\hline F-Statistic & $1071.01 \mathrm{a}$ & & & & & \\
\hline R2/Pseudo-R2 & 0.8777 & 0.6233 & 0.6637 & 0.6801 & 0.6987 & 0.6830 \\
\hline Adj R-square & 0.8769 & & & & & \\
\hline Observation & 902 & 902 & 902 & 902 & 902 & 902 \\
\hline
\end{tabular}

$\mathrm{a}=0.01, \mathrm{~b}=0.05, \mathrm{c}=0.10$

depicts a positive impact of renewable energy consumption on the environmental quality of the non-oil region. This is in line with the theory and authors expectation. This finding supports the findings by Bekun et al. (2019), Gyamfi et al (2021e), Steve et al (2021), and Aseidu et al. (2021). The findings according to the OLS-cum-quantile regression on oil countries are similar to those of the non-oil countries except in few cases with varying coefficients. The coefficients of the economic growth and FDI in all the quantiles of oil countries show that economic growth and FDI exert stronger negative influence on environment than those of non-oil countries. This is expected of the analysis because the oil countries have high tendencies of attracting greater percentage of foreign investors both in the form of transnational corporations and on individual basis who are players in oil businesses. The economic activities in the oil countries are equally expected to be greater than those of the non-oil countries considering the influx of foreign investors due to the availability of oil resources. Considering the development history of the region, most of the oil-dependent 
countries in the African region tend toward an increase in economic growth because of resource revenue which does not necessarily mean good livelihood of the masses.

However, the findings from both OLS and quantile regression of the combined data of both regions (oil and non-oil countries in sub-Saharan Africa) attest to the findings from the individual regions. The findings are really interesting with some levels of similarities with individual regions but on a varying degree in the coefficients and the amount of negative relationship that exists among the selected variables. A mixture of negative and positive relationships existed between tourism arrival, urbanization, and FDI and carbon emission for the case of non-oil countries. Specifically, a negative relationship is found between tourism arrivals, urbanization, and FDI and carbon emission in $50^{\text {th }}$ quantile of tourism arrival, $90^{\text {th }}$ quantile of urbanization, and $90^{\text {th }}$ quantile of FDI, respectively. The same scenarios occurred in the combined regression in the case of tourism arrival, FDI, and urbanization in greater dimension. Thus, a negative relationship occurred between tourism arrival, urbanization, and FDI and carbon emission in the $5^{\text {th }}, 25^{\text {th }}, 50^{\text {th }}$ for the case of tourism arrival and across all the quantiles for the case urbanization, and in the $25^{\text {th }}$ quantile for the case of FDI. The OLS findings for the both variables show a negative relationship between tourism arrival, urbanization, and carbon emission. The findings that hinge on tourism arrival, FDI, and urbanization are a good story for the regions, especially the non-oil region. This is a pointer toward maintaining a good environment with good policies framed around the tourism arrival, urbanization, and FDI.

\section{Robustness Result}

For robustness purposes, the fully modified lease square (FMOLS) proposed by Pesaran et al. (1999) was utilized and the outcomes affirm that of the quantile regress utilized for the study. For both non-oil and oil countries, it was observed that tourism, economic growth, FDI, energy use, and urbanization all increase emission within these countries, while renewable energy intake decreases pollution. However, in the combined countries, tourism, economic growth, FDI, and energy use increase pollution, while renewable energy intake and urbanization decrease pollution for the countries as highlighted in Table 8.

Granger causality estimation and analysis were equally performed for forecasting and robust check on the results from the both OLS and quantile regression. Most times after the confirmation of cointegration and long-run relationship, granger causality is advised to be estimated in support of the findings of the regression. Granger causality estimate was done for the three groups (oil, non-oil, and combined), and the results are shown in Table 9 as follows: Unidirectional transmission is found passing into carbon emission from tourism arrival for oil countries, from FDI to carbon emission for non-oil countries and combined group, from economic growth to carbon emission for non-oil countries and combined group, from renewable energy use to carbon emission for non-oil countries, from carbon emission to renewable energy use for the combined group, from urbanization to carbon emission for non-oil countries, and from carbon emission to urbanization for the combined group. Furthermore, bidirectional transmission is found between renewable energy use and carbon emission for the oil countries, and between urbanization and carbon emission for the oil countries. The findings from the granger causality attest to and support the regression results, hence unidirectional causal transmission from both tourism arrival and FDI to carbon emission, bidirectional causal transmission between renewable energy use and carbon emission, and between urbanization and carbon emission. This shows the tendency of tourism arrival, FDI, urbanization, and renewable energy consumption impacting favorably on the environment of the regions in this study.
Table 8 Fully modified least square (FMOLS)

\begin{tabular}{llll}
\hline & $\begin{array}{l}\text { NON-OIL COUN- } \\
\text { TRIES }\end{array}$ & OIL COUNTRIES & $\begin{array}{l}\text { COMBINATION OF OIL } \\
\text { AND NON-OIL COUN- } \\
\text { TRIES }\end{array}$ \\
\hline LnTA & $0.016 \mathrm{~b}$ & $0.036 \mathrm{~b}$ & $0.056 \mathrm{~b}$ \\
FDI & $0.008 \mathrm{~b}$ & $0.025 \mathrm{c}$ & $0.025 \mathrm{c}$ \\
LnGDP & $0.709 \mathrm{a}$ & $0.737 \mathrm{a}$ & $0.728 \mathrm{a}$ \\
LnREC & $-0.402 \mathrm{c}$ & $-0.002 \mathrm{c}$ & $-0.031 \mathrm{c}$ \\
LnNREC & $0.530 \mathrm{a}$ & $0.291 \mathrm{a}$ & $0.512 \mathrm{a}$ \\
LnUB & $0.076 \mathrm{c}$ & $0.012 \mathrm{~b}$ & $-0.104 \mathrm{c}$ \\
R-squared & 0.972 & 0.979 & 0.984 \\
Adjusted R-squared & 0.968 & 0.977 & 0.982 \\
\hline
\end{tabular}

$\mathrm{a}=0.01, \mathrm{~b}=0.05, \mathrm{c}=0.10$ 
Table 9 The DH Granger causality evidence

\begin{tabular}{|c|c|c|c|}
\hline & $\begin{array}{l}\text { NON-OIL COUN- } \\
\text { TRIES }\end{array}$ & OIL COUNTRIES & $\begin{array}{l}\text { COMBINATION OF OIL } \\
\text { AND NON-OIL COUN- } \\
\text { TRIES }\end{array}$ \\
\hline Null Hypothesis & W-Stat & W-Stat & W-Stat \\
\hline $\mathrm{LnTA} / \mathrm{LnCO}_{2}$ & 0.528 & $3.640 \mathrm{~b}$ & 0.239 \\
\hline $\mathrm{LnCO}_{2} \nearrow \mathrm{LnTA}$ & 0.098 & 0.016 & 1.325 \\
\hline $\mathrm{FDI} / \mathrm{LnCO}_{2}$ & $7.787 \mathrm{a}$ & 1.625 & $5.948 \mathrm{a}$ \\
\hline $\mathrm{LnCO}_{2} \nearrow \mathrm{FDI}$ & 0.696 & 2.079 & 2.028 \\
\hline $\mathrm{LnGDP} / \mathrm{LnCO}_{2}$ & $7.805 \mathrm{a}$ & 0.257 & $3.203 b$ \\
\hline $\mathrm{LnCO}_{2} \nearrow \mathrm{LnGDP}$ & 0.729 & 1.394 & 0.804 \\
\hline $\mathrm{LnNREC} / \mathrm{LnCO}_{2}$ & 1.040 & 0.988 & 1.181 \\
\hline $\mathrm{LnCO}_{2} \nearrow \mathrm{LnNREC}$ & 1.452 & 0.123 & 0.499 \\
\hline $\mathrm{LnREC} / \mathrm{LnCO}_{2}$ & $0.004 \mathrm{c}$ & $3.730 \mathrm{~b}$ & 0.718 \\
\hline $\mathrm{LnCO}_{2} / \mathrm{LnREC}$ & 3.001 & $5.101 \mathrm{a}$ & $6.323 \mathrm{a}$ \\
\hline $\mathrm{LnUB} / \mathrm{LnCO}_{2}$ & $3.055 \mathrm{~b}$ & $2.529 \mathrm{c}$ & 0.773 \\
\hline $\mathrm{LnCO}_{2} \nearrow \mathrm{LnUB}$ & 2.281 & $3.482 b$ & $8.971 \mathrm{a}$ \\
\hline
\end{tabular}

$\mathrm{a}=0.01, \mathrm{~b}=0.05, \mathrm{c}=0.10$

\section{Concluding remark and policy implications}

This is an inclusive panel studies of the sub-Saharan African countries' environmental performance under tourism growth and FDI growth policies. Emphasis is laid on tourism and FDI because sub-Saharan African countries are considered new tourism and FDI routs with regards to her richness in both cultural heritage and resources endowments. We apply different scientific approaches such as OLS, quantile analysis, and Granger causality in this study to ascertain the real impacts of tourism and FDI on the environmental performance of the regions. Our findings and justifications are based on the outcomes of the three mentioned approaches. Findings from OLS and quantile regressions revealed a mixed impact of both policies (tourism and FDI) on the environmental performance of the studied region. Hence, a negative and positive influence is recorded, but drawing from the findings in the combined regression, we conclude that tourism and FDI policies have tendency of impacting favorably on the environment of the regions in our studies if regulations are implemented and monitored without biasedness from the government officials.

Following the findings from our study, the following policies are recommended for the countries of the sub-Saharan Africa. Strict environmental guidelines and regulations are necessary for controlling the unhealthy and undue economic activities that are suspected to impact negatively on the environment. Emission target is worth implementing in the industrial areas to reduce the emission from the urban areas. The defaulters will be made to pay a bit extra tax. Financing and decentralizing the energy system to a more renewable energy source will be a great advancement into decarburizing and achieving some level of green economy in the region. Countries of the region are encouraged to embark on massive sensitization of the masses on the importance of healthy environment so as to reduce some activities with high tendencies of affecting environment negatively. Public transport system should be introduced and maintained to discourage the excessive usage of automobile that run on fossil fuels which will reduce excessive emission from the automobiles.

Furthermore, our findings on the breakdown of foreign production have no substantial ramifications for the countries of sub-Saharan Africa, as previously stated. State governments in sub-Saharan Africa should strive to match the criteria of the global market in order to avoid being considered pollution hot spots. For example, increasing the entry barrier to dirty industry, regulating the export of pollutionproducing items, and stimulating the development of new export competitive advantages are all possible. In addition, the countries of sub-Saharan Africa must gradually and efficiently adjust the economic growth trend in order to achieve balanced and stable progress through supply-side reform.

Additionally, decision-makers in sub-Saharan Africa's countries should promote sustainable and cleaner energy sources for economies in order to reduce the continent's dependency on fossil fuel emissions. This can be accomplished through the effective use of renewable energy's environmental attributes (such as solar, wind power, and hydraulic energy, among others).

Conclusively, this study has implication to other developing countries, especially the ones close to the sub-Saharan regions. Also, the topic can still be investigated with other variables such as institutional quality to have insight into the effectiveness of government regulation on the environmental performance of the region. 


\section{Appendix}

Table 10 List of Countries

\begin{tabular}{|c|c|}
\hline OIL COUNTRIES & NON-OIL COUNTRIES \\
\hline Algeria & Benin \\
\hline Angola & Burkina Faso \\
\hline Cameroon & Burundi \\
\hline Chad & Cabo Verde \\
\hline Congo, Rep & Central African Republic \\
\hline Cote d'Ivoire & Comoros \\
\hline Egypt & Eritrea \\
\hline Gabon & Ethiopia \\
\hline Ghana & Gambia, The \\
\hline Libya & Guinea \\
\hline Morocco & Guinea-Bissau \\
\hline Nigeria & Kenya \\
\hline Sudan & Lesotho \\
\hline \multirow[t]{14}{*}{ Tunisia } & Madagascar \\
\hline & Malawi \\
\hline & Mali \\
\hline & Mauritania \\
\hline & Mozambique \\
\hline & Niger \\
\hline & Rwanda \\
\hline & Senegal \\
\hline & Sierra Leone \\
\hline & Tanzania \\
\hline & Togo \\
\hline & Uganda \\
\hline & Zambia \\
\hline & Zimbabwe \\
\hline
\end{tabular}

Acknowledgements Author gratitude is extended to the prospective editor(s) and reviewers that will/have spared time to guide toward a successful publication. The authors of this article also assure that they follow the Springer publishing procedures and agree to publish it as any form of access article confirming to subscribe access standards and licensing.

Authors' contributions The first author (Dr. Ruth Bamidele) was responsible for the conceptual construction of the study's idea. The second author (Prof. Dr. Edmund Utom) handled the literature section, while the third authors (Dr. Bright Akwasi Gyamfi) managed the data gathering and preliminary analysis and Dr. Festus Victor Bekun is responsible for proofreading and manuscript editing.

Funding I hereby declare that there is no form of funding received for this study.

Availability of data and materials The data for this present study are sourced from the World Development Indicators (https://data.world bank.org/). The current specific data can be made available upon request, but are available and downloadable at the earlier mentioned database and Web link.

\section{Declarations}

Ethical approval The authors mentioned in the manuscript have agreed for authorship read and approved the manuscript, and given consent for submission and subsequent publication of the manuscript.

Consent to participate Not Applicable.

Consent to publish Applicable.

Competing interests I wish to disclose here that there are no potential conflicts of interest at any level of this study.

\section{References}

Adedoyin FF, Bekun FV (2020) Modelling the interaction between tourism, energy consumption, pollutant emissions and urbanization: renewed evidence from panel VAR. Environ Sci Pollut Res 27(31):38881-38900

Adedoyin FF, Zakari A (2020) Energy consumption, economic expansion, and $\mathrm{CO} 2$ emission in the UK: the role of economic policy uncertainty. Science of the Total Environment 738:140014

Adedoyin FF, Agboola PO, Ozturk I, Bekun FV, Agboola MO (2021) Environmental consequences of economic complexities in the EU amidst a booming tourism industry: Accounting for the role of brexit and other crisis events. Journal of Cleaner Production 305:127117

Adedoyin FF, Alola AA, Bekun FV (2020) An assessment of environmental sustainability corridor: the role of economic expansion and research and development in EU countries. Science of the total environment 713:136726

Adedoyin FF, Alola AA, Bekun FV (2021) The alternative energy utilization and common regional trade outlook in EU-27: evidence from common correlated effects. Renewable and Sustainable Energy Reviews 145:111092

Adedoyin FF, Gumede MI, Bekun FV, Etokakpan MU, BalsalobreLorente D (2020) Modelling coal rent, economic growth and CO2 emissions: does regulatory quality matter in BRICS economies? Science of the Total Environment 710:136284

Adedoyin FF, Nathaniel S, Adeleye N (2021c) An investigation into the anthropogenic nexus among consumption of energy, tourism, and economic growth: do economic policy uncertainties matter? Environ Sci Pollut Res 28(3):2835-2847

Adedoyin, F. F., Ozturk, I., Bekun, F. V., Agboola, P. O., \& Agboola, M. O. (2021d). Renewable and Non-renewable Energy Policy Simulations for abating emissions in a complex economy: Evidence from the Novel Dynamic ARDL. Renewable Energy.

Alola AA, Alola UV (2018) Agricultural land usage and tourism impact on renewable energy consumption among Coastline Mediterranean Countries. Energy \& Environment 29(8):1438-1454

Alola AA, Alola UV (2019) The dynamics of tourism-refugeeism on house prices in Cyprus and Malta. J Int Migr Integr 20(2):521-536

Anser MK (2019) Impact of energy consumption and human activities on carbon emissions in Pakistan: application of STIRPAT model. Environ Sci Pollut Res 26(13):13453-13463

Asiedu, B. A., Gyamfi, B. A., \& Oteng, E. (2021). How do trade and economic growth impact environmental degradation? New evidence and policy implications from the ARDL approach. Environmental Science and Pollution Research, 1-9.

Aslan A, Altinoz B, Özsolak B (2021) The nexus between economic growth, tourism development, energy consumption, and CO 2 emissions in Mediterranean countries. Environ Sci Pollut Res 28(3):3243-3252 
Baloch MA, Ozturk I, Bekun FV, Khan D (2021) Modeling the dynamic linkage between financial development, energy innovation, and environmental quality: Does globalization matter? Bus Strateg Environ 30(1):176-184

Balsalobre-Lorente D, Leitão NC (2020) The role of tourism, trade, renewable energy use and carbon dioxide emissions on economic growth: evidence of tourism-led growth hypothesis in EU-28. Environ Sci Pollut Res 27(36):45883-45896

Balsalobre-Lorente D, Shahbaz M, Roubaud D, Farhani S (2018) How economic growth, renewable electricity and natural resources contribute to CO2 emissions? Energy Policy 113:356-367

Bamidele, R., Ozturk, I., Gyamfi, B. A., \& Bekun, F. V. (2021). Tourism-induced pollution emission amidst energy mix: evidence from Nigeria. Environmental Science and Pollution Research, 1-10.

Bataka H (2020) Globalization and Environmental Pollution in Sub-Saharan Africa. African Journal of Economic Review 9(1):191-205

Bekun FV, Alola AA, Sarkodie SA (2019) Toward a sustainable environment: Nexus between $\mathrm{CO} 2$ emissions, resource rent, renewable and nonrenewable energy in 16-EU countries. Sci Total Environ 657:1023-1029

Bekun, F. V., Alola, A. A., Gyamfi, B. A., \& Ampomah, A. B. (2021a). The environmental aspects of conventional and clean energy policy in sub-Saharan Africa: is N-shaped hypothesis valid?. Environmental Science and Pollution Research, 1-14.

Bekun, F. V., Alola, A. A., Gyamfi, B. A., \& Yaw, S. S. (2021b). The relevance of EKC hypothesis in energy intensity real-output tradeoff for sustainable environment in EU-27. Environmental Science and Pollution Research, 1-12.

Bekun, F. V., Gyamfi, B. A., Onifade, S. T., \& Agboola, M. O. (2021c). Beyond the environmental Kuznets Curve in E7 economies: Accounting for the combined impacts of institutional quality and renewables. Journal of Cleaner Production, 127924.

Bello MO, Solarin SA, Yen YY (2018) The impact of electricity consumption on $\mathrm{CO} 2$ emission, carbon footprint, water footprint and ecological footprint: the role of hydropower in an emerging economy. J Environ Manag 219:218-230

Bera AK, Galvao AF, Montes-Rojas GV, Park SY (2016) Asymmetric laplace regression: maximum likelihood, maximum entropy and quantile regression. Journal of Econometric Methods 5(1):79-101

De Silva PNK, Simons SJR, Stevens P (2016) Economic impact analysis of natural gas development and the policy implications. Energy Policy 88:639-651

De Vita G, Katircioglu S, Altinay L, Fethi S, Mercan M (2015) Revisiting the environmental Kuznets curve hypothesis in a tourism development context. Environ Sci Pollut Res 22(21):16652-16663

Dong K, Sun R, Li H, Liao H (2018) Does natural gas consumption mitigate $\mathrm{CO} 2$ emissions: testing the environmental Kuznets curve hypothesis for 14 Asia-Pacific countries. Renew Sust Energ Rev 94:419-429

Driscoll JC, Kraay AC (1998) Consistent covariance matrix estimation with spatially dependent panel data. Rev Econ Stat 80(4):549-560

El Menyari, Y. (2021). The effects of international tourism, electricity consumption, and economic growth on $\mathrm{CO} 2$ emissions in North Africa. Environmental Science and Pollution Research, 1-11.

Gao, J., \& Zhang, L. (2019). Exploring the dynamic linkages between tourism growth and environmental pollution: new evidence from the Mediterranean countries. Current Issues in Tourism, 1-17.

Guangyue X, Deyong S (2011) An empirical study on the environmental Kuznets curve for China's carbon emissions: based on provincial panel data. Chinese Journal of Population Resources and Environment 9(3):66-76

Gyamfi BA, Adebayo TS, Bekun FV, Agyekum EB, Kumar NM, Alhelou HH, Al-Hinai A (2021a) Beyond environmental Kuznets curve and policy implications to promote sustainable development in Mediterranean. Energy Rep 7:6119-6129
Gyamfi, B. A., Bein, M. A., Adedoyin, F. F., \& Bekun, F. V. (2021b). How does energy investment affect the energy utilization-growthtourism nexus? Evidence from E7 Countries. Energy \& Environment, $0958305 \mathrm{X} 21999752$.

Gyamfi, B. A., Bein, M. A., Adedoyin, F. F., \& Bekun, F. V. (2021c). To what extent are pollutant emission intensified by international tourist arrivals? Starling evidence from G7 Countries. Environment, Development and Sustainability, 1-22.

Gyamfi BA, Bein MA, Udemba EN, Bekun FV (2021) Investigating the pollution haven hypothesis in oil and non-oil sub-Saharan Africa countries: Evidence from quantile regression technique. Resources Policy 73:102119

Gyamfi BA, Ozturk I, Bein MA, Bekun FV (2021e) An investigation into the anthropogenic effect of biomass energy utilization and economic sustainability on environmental degradation in E7 economies. Biofuels, Bioprod Biorefin 15(3):840-851

Hanif I (2018) Impact of economic growth, nonrenewable and renewable energy consumption, and urbanization on carbon emissions in Sub-Saharan Africa. Environ Sci Pollut Res 25(15):15057-15067

Hübler M (2017) The inequality-emissions nexus in the context of trade and development: a quantile regression approach. Ecol Econ 134:174-185

Im KS, Pesaran MH, Shin Y (2003) Testing for unit roots in heterogeneous panels. J Econ 115(1):53-74

Iwata H, Okada K (2013) Greenhouse gas emissions and the role of the Kyoto Protocol. Advance online publication, Environmental Economics and Policy Studies. https://doi.org/10.1007/ s10018-012-0047-1

Katircioglu ST, Feridun M, Kilinc C (2014) Estimating tourisminduced energy consumptionand $\mathrm{CO} 2$ emissions: The case of Cyprus. Renew Sustain Energy Rev 29:634-640

Katircioglu ST (2014) International tourism, energy consumption, and environmental pollution: The case of Turkey. Renew Sustain Energy Rev 36:180-187

Lasisi TT, Eluwole KK, Alola UV, Aldieri L, Vinci CP, Alola AA (2021) Do Tourism Activities and Urbanization Drive Material Consumption in the OECD Countries? A Quantile Regression Approach Sustainability 13(14):7742

Lasisi TT, Alola AA, Eluwole KK, Ozturen A, Alola UV (2020) The environmental sustainability effects of income, labour force, and tourism development in OECD countries. Environ Sci Pollut Res 27(17):21231-21242

Lee JW, Brahmasrene T (2016) Tourism effects on the environment and economic sustainability of sub-Saharan Africa. Int J Sust Dev World 23(3):221-232

Mensah IA, Sun M, Gao C, Omari-Sasu AY, Zhu D, Ampimah BC, Quarcoo A (2019) Analysis on the nexus of economic growth, fossil fuel energy consumption, $\mathrm{CO} 2$ emissions and oil price in Africa based on a PMG panel ARDL approach. J Clean Prod 228:161-174

Mitchell, E. J. S., Ting, Y., Allan, J., Lea-Langton, A. R., Spracklen, D. V., McFiggans, G., ... \& Jones, J. M. (2019). Pollutant emissions from improved cookstoves of the type used in sub-Saharan Africa. Combustion Science and Technology, 1-21.

Nathaniel, S., Aguegboh, E., Iheonu, C., Sharma, G., \& Shah, M. (2020). Energy consumption, FDI, and urbanization linkage in coastal Mediterranean countries: re-assessing the pollution haven hypothesis. Environmental Science and Pollution Research, 1-14.

Nissan E, Galindo MA, Méndez MT (2011) Relationship between tourism and economic growth. Serv Ind J 31(10):1567-1572

Onifade ST, Gyamfi BA, Haouas I, Bekun FV (2021) Re-examining the roles of economic globalization and natural resources consequences on environmental degradation in E7 economies: Are human capital and urbanization essential components? Resources Policy 74:102435

Ozpolat, A., Ozsoy, F. N., \& Destek, M. A. (2021). Investigating the Tourism Originating CO 2 Emissions in Top 10 Tourism-Induced 
Countries: Evidence from Tourism Index. In Strategies in Sustainable Tourism, Economic Growth and Clean Energy (pp. 155-175). Springer, Cham.

Ozturk I (2016) The relationships among tourism development, energy demand, and growth factors in developed and developing countries. Int J Sust Dev World 23(2):122-131

Ozcan CC, Bekun FV, Nazlioglu S (2021) Tourism-induced pollutant emissions in Mediterranean countries: Evidence from panel causality analysis. Int Soc Sci J 71(241-242):261-281

Pesaran MH (2007) A simple panel unit root test in the presence of cross-section dependence. J Appl Econ 22(2):265-312

Pesaran MH, Shin Y, Smith RP (1999) Pooled mean group estimation of dynamic heterogeneous panels. J Am Stat Assoc 94(446):621-634

Pesaran MH (2015) Testing weak cross-sectional dependence in large panels. Econom. Rev. 34(6-10):1089-1117

Qureshi MI, Elashkar EE, Shoukry AM, Aamir A, Mahmood NHN, Rasli AM, Zaman K (2019) Measuring the ecological footprint of inbound and outbound tourists: evidence from a panel of 35 countries. Clean Technol Environ Policy 21(10):1949-1967

Salman M, Long X, Dauda L, Mensah CN, Muhammad S (2019) Different impacts of export andimport on carbon emissions across 7 ASEAN countries: a panel quantile regression approach. Sci Total Environ 686:1019-1029

Sarkodie SA, Strezov V (2019) Effect of foreign direct investments, economic development and energy consumption on greenhouse gas emissions in developing countries. Sci Total Environ 646:862-871

Sarpong SY, Bein MA, Gyamfi BA, Sarkodie SA (2020) The impact of tourism arrivals, tourism receipts and renewable energy consumption on quality of life: A panel study of Southern African region. Heliyon 6(11):e05351

Shahbaz, M., \& Lean, H. H. \& Shahbaz Sh, M. (2010). Environmental Kuznets Curve and the Role of Energy Consumption in Pakistan. Development Research Unit, Discussion Paper DEVDP, 10(05).

Shahbaz M, Khan S, Tahir MI (2013) The dynamic links between energy consumption, economic growth, financial development and trade in China: fresh evidence from multivariate framework analysis. Energy Economics 40:8-21

Shaheen K, Zaman K, Batool R, Khurshid MA, Aamir A, Shoukry AM, Gani S (2019) Dynamic linkages between tourism, energy, environment, and economic growth: evidence from top 10 tourisminduced countries. Environ Sci Pollut Res 26(30):31273-31283

Sharif A, Baris-Tuzemen O, Uzuner G, Ozturk I, Sinha A (2020) Revisiting the role of renewable and non-renewable energy consumption on Turkey's ecological footprint: Evidence from Quantile ARDL approach. Sustainable Cities and Society 57:102138

Shittu W, Adedoyin FF, Shah MI, Musibau HO (2021) An investigation of the nexusbetween natural resources, environmental performance, energy security and environmental degradation: Evidence from Asia. Resources Policy 73:102227

Solarin SA, Al-Mulali U (2018) Influence of foreign direct investment on indicators of environmental degradation. Environ Sci Pollut Res 25(25):24845-24859

Ssali MW, Du J, Mensah IA, Hongo DO (2019) Investigating the nexus among environmental pollution, economic growth, energy use, and foreign direct investment in 6 selected sub-Saharan African countries. Environ Sci Pollut Res 26(11):11245-11260

Steve, Y. S., Murad, A. B., Gyamfi, B. A., Bekun, F. V., \& Uzuner, G. (2021). Renewable energy consumption a panacea for Sustainable economic growth: panel causality analysis for African blocs. International Journal of Green Energy, 1-10.

Udemba EN (2019) Triangular nexus between foreign direct investment, international tourism, and energy consumption in the Chinese economy: accounting for environmental quality. Environmental Science and Pollution Research 26(24):24819-24830

Westerlund J (2007) Testing for error correction in panel data. Oxf Bull Econ Stat 69(6):709-748

World Health Organization. (2016). World health statistics 2016: monitoring health for the SDGs sustainable development goals. World Health Organization.

Yusuf, M. A. (2016). 'Performance Assessment of Tourism Sector as a Vital Tool of Economic Growth in Nigeria. International Journal of Academic Research in Business and Social Sciences Vol. 6, No. 10

Zaidi S, Saidi K (2018) Environmental pollution, health expenditure and economic growth in the Sub-Saharan Africa countries: Panel ARDL approach. Sustain Cities Soc 41:833-840

Zhang Y, Zhang S (2018) The impacts of GDP, trade structure, exchange rate and FDI inflows on China's carbon emissions. Energy Policy 120:347-353

Zhu H, Duan L, Guo Y, Yu K (2016a) The effects of FDI, economic growth, energy consumption on carbon emissions in ASEAN-5: evidence from panel quantile regression. Econ Model 58:237-248

Zhu H, Duan L, Guo Y, Yu K (2016b) The effects of FDI, economic growth and energy consumption on carbon emissions in ASEAN-5: evidence from panel quantile regression. Econ Model $58: 237-248$

Publisher's note Springer Nature remains neutral with regard to jurisdictional claims in published maps and institutional affiliations. 